\title{
EFEKTIVITAS HUKUM HUMANITER INTERNASIONAL DALAM MELINDUNGI CAGAR BUDAYA DI NEGARA KONFLIK
}

\author{
Mirsa Astuti \\ Fakultas Hukum Universitas Muhammadiyah Suatera Utara \\ Jl. Kapt. Mukhtar Basri No. 3, Medan - Sumatera Utara \\ Email: mirsaastuti@umsu.ac.id
}

\begin{abstract}
Abstrak
Perang adalah naluri untuk membela diri yang berlaku baik dalam hubungan antara manusia dan hubungan antar bangsa. Karena itu sejarah perang sama tuanya dengan sejarah umat manusia. Dalam konflik bersenjata ada banyak benda budaya yang dihancurkan oleh bom atau peluru yang digunakan untuk menyerang target musuh oleh pihak-pihak yang berkonflik. Meskipun perlindungan benda-benda warisan budaya telah diatur dalam Konvensi Internasional, masih ada perilaku yang menyebabkan kerusakan bahkan pada penghancuran benda-benda budaya. Prosedur untuk mengumpulkan data adalah dalam bentuk dokumentasi catatan atau kutipan, pencarian literatur hukum, buku-buku dan lain-lain yang berkaitan dengan identifikasi masalah baik offline maupun online yang kemudian dianalisis melalui metode analisis isi (metode analisis konten) dengan fokus pada masalah seberapa efektif undang-undang ini adalah kemanusiaan internasional dalam melindungi warisan budaya di negara-negara konflik. Hasil penelitian diketahui bahwa benda budaya adalah identitas budaya masyarakat, sehingga serangan terhadap mereka sering meningkatkan eskalasi konflik. Serangan bom udara dan jarak jauh meningkatkan kerusakan pada benda-benda budaya yang dihasilkan dari konflik bersenjata.
\end{abstract}

\section{Kata Kunci: Humaniter, Cagar, Budaya, Negara, Konflik}

\section{Abstract}

War is an instinct for self-defense that applies both in association between humans and relationships between nations. Therefore the history of war is as old as the history of mankind. In armed conflict there are a lot of cultural objects which are destroyed by bombs or bullets used to attack enemy targets by parties in conflict. Although protection of cultural heritage objects has been regulated in an International Convention, there are still behaviors that cause damage to even the destruction of cultural objects. The procedure for collecting data is in the form of documentation of notes or quotes, search of legal literature, books and others related to the identification of problems both offline and online which are then analyzed through the content analysis method (centent analysis method) with a focus on the issue of how effective the law is international humanitarian in protecting cultural heritage in conflict countries. The results of the study it is known that cultural objects are the cultural identity of the community, so that attacks on them often increase conflict escalation. Air and remote bombing attacks increase damage to cultural objects resulting from armed conflict.

Keywords: Humaniter, Reverse, Culture, State, Conflict

\section{PENDAHULUAN}

Hukum perang atau sering disebut dengan hukum Humaniter memiliki sejarah yang sama tuanya dengan peradaban manusia. Hukum Humaniter Internasional adalah seperangkat aturan yang membatasi dampak sengketa bersenjata atas dasar pertimbangan kemanusiaan. Hukum Humaniter Internasional (HHI) melindungi orang yang tidak (atau tidak lagi) ikut serta dalam pertikaian dan membatasi sarana serta cara berperang (ICRC, 2010, h. 6). Hukum 


\section{DEIFGA LATA}

Jurnal Ilmu Hukum

FAKULTAS HUKUM UMSU
Efektivitas Hukum Humaniter...(Mirsa Astuti)

Volume 3 Nomor 1, Januari-Juni 2018, 96-107 DOI: $\underline{\text { https://doi.org/10.30596/dll.v3i1.3143 }}$

Humaniter mencoba untuk mengatur agar suatu perang dapat dilakukan dengan lebih memperhatikan prinsip-prinsip kemanusian.

Untuk sampai kepada bentuknya sekarang HHI telah mengalami perkembangan yang sangat panjang. Selama masa tersebut banyak upaya yang dilakukan untuk memanusiawikan perang dengan cara memberikan perlindungan. Bentuk perlindungan diberikan baik kepada orang-orang dari kekejaman perang mau pun benda-benda yang merupakan benda bersejarah dari suatu negara. Saat melakukan serangan militer terhadap pihak lawan haruslah berhati-hati agar tidak menimbulkan kerusakan pada bangunan-bangunan yang telah mendapat perlindungan dari Hukum Humaniter Internasional. Masing-masing pihak yang berkonflik harus menghormati benda-benda budaya atau bangunan-bangunan seperti, rumah ibadah, tempat pendidikan dan monumen-monumen bersejarah yang diatur dalam aturan 38 butir (a) aturan-aturan Hukum Humaniter Kebiasaan, yang berbunyi:

Dalam pelaksanaan operasi militer, kehati-hatian khusus harus dilakukan untuk menghindari timbulnya kerusakan terhadap bangunan-bangunan yang didedikasikan untuk tujuan keagamaan, seni, ilmu pengetahuan, pendidikan, atau amal dan terhadap monumen-monumen bersejarah, kecualai jika bangunan-bangunan tersebut merupakan sasaran militer (ICRC, 2005, h. 30).

Pada konteks efektivitas hukum Humaniter internasional dalam melindungi cagar budaya di negara konflik, Sehingga yang menjadi fokus permasalahan dalam penulisan ini adalah Bagaimana efektivitas hukum Humaniter internasional dalam melindungi cagar budaya di negara konflik? Dengan harapan tulisan ini dapat bermanfaat baik secara teori maupun praktis bagi khalayak luas dalam rangka efektivitas hukum Humaniter internasional dalam melindungi cagar budaya di negara konflik.

\section{METODE PENELITIAN}

Penulisan ini menggunakan metode penelitian hukum yuridis normatif (normatif research), yaitu penelitian hukum yang dilakukan dengan cara meneliti bahan pustaka atau data skunder (Seokanto dan Sri Muji, 2003, h. 15). Spesifikasi penelitian dalam penulisan ini berupa penelitian deskriptif analistis. Deskriptif adalah menunjukan komparasi atau hubungan seperangkat data dengan seperangkat data yang lain, dan maksudnya adalah untuk memberikan gambaran, menelaah, menjelaskan dan menganalisis (Soekanto, 1996, h. 63).

Sesuai jenis dan sifat penelitiannya, maka sumber data yang digunakan dalam penulisan ini adalah data skunder yang terdiri dari bahan hukum primer berupa; Aturan hukum yang terkait dengan hukum internasional. Bahan hukum sekunder terdiri dari buku-buku, jurnal ilmiah, makalah dan artikel ilmiah yang dapat memberi penjelasan tentang bahan hukum primer. Bahan hukum tersier; berupa Kamus Besar Bahasa Indonesia (KBBI) dan lain sebagainya dalam menemukan defenisi dari istilah-istilah dalam membahas tentang efektivitas hukum Humaniter internasional dalam melindungi cagar budaya di negara konflik.

Prosedur yang digunakan untuk mengumpulkan data dalam penilitian ini berupa dokumentasi yaitu pedoman yang digunakan berupa catatan atau kutipan, penelusuran literatur hukum, buku-buku dan lainnya yang bertalian dengan identifikasi masalah dalam penilitian ini dengan cara offline maupun online. Analisa bahan hukum dilakukan dengan menggunakan metode analisa konten (centent analysis method) yang dilakukan dengan menguraikan materi peristiwa hukum atau produk hukum secara rinci guna memudahkan 
DEIFGA LATA

Jurnal Ilmu Hukum

FAKULTAS HUKUM UMSU
Efektivitas Hukum Humaniter...(Mirsa Astuti)

Volume 3 Nomor 1, Januari-Juni 2018, 96-107 DOI: $\underline{\text { https://doi.org/10.30596/dll.v3i1.3143 }}$

interpretasi dalam pembahasan (Marzuki, 2011, h. 171).

\section{PEMBAHASAN \\ Efektivitas Hukum Humaniter Internasional Dalam Melindungi Cagar Budaya Di Negara Konflik}

\section{Pengertian dan Tujuan Hukum Humaniter}

Istilah Hukum Humaniter atau lengkapnya disebut International Humanitarian Law Applicable in Armed Conflict, pada awalnya dikenal sebagai hukum perang (laws of war), yang kemudian berkembang menjadi hukum sengketa bersenjata (laws of arms conflict), dan pada akhirnya dikenal dengan istilah hukum Humaniter. Istilah Hukum Humaniter sendiri dalam kepustakaan hukum internasional merupakan istilah yang relatif baru. Istilah ini lahir sekitar tahun 1970-an dengan diadakannya Conference of Government Expert on the Reaffirmation and Development in Armed Conflict pada tahun 1971.Sebagai bidang baru dalam hukum internasional, maka terdapat rumusan atau definisi mengenai hukum Humaniter:

1) Mochtar Kusumaatmadja: "Bagian dari hukum yang mengatur ketentuan-ketentuan perlindungan korban perang, berlainan dengan hukum perang yang mengatur perang itu sendiri dan segala sesuatu yang menyangkut cara melakukan perang itu sendiri" (Mochtar 1980, h. 5).

2) S.R Sianturi: "Hukum yang mengatur mengenai suatu sengketa bersenjata yang timbul antara dua atau lebih pihak-pihak yang bersengketa, walaupun keadaan sengketa tersebut tidak diakui oleh salah satu pihak".

3) Panitia tetap hukum Humaniter, departemen hukum dan perundang-undangan merumuskan sebagai berikut; hukum Humaniter sebagai keseluruhan asas, kaedah dan ketentuan internasional, baik tertulis maupun tidak tertulis, yang mencakup hukum perang dan hak asasi manusia, bertujuan untuk menjamin penghormatan terhadap harkat dan martabat seseorang.

Hukum Humaniter tidak dimaksudkan untuk melarang perang akan tetapi bertujuan mengurangi atau membatasi penderitaan individu-individu dan membatasi kebuasan dalam konflik bersenjata. Hukum Humaniter mencoba untuk mengatur agar suatu perang dapat dilakukan dengan lebih memperhatikan prinsip-prinsip kemanusiaan. Sebagaimana dikemukakan oleh Mohammad Bedjaoui, bahwa tujuan hukum Humaniter adalah memanusiaakan perang. Di samping itu ada beberapa tujuan hukum Humaniter (Arlina permanasari dkk, 1999, h. 12):

1) Memberikan perlindungan terhadap kombatan maupun penduduk sipil dari penderitaan yang tidak perlu ( unnecessary suffering).

2) Menjamin hak asasi manusia yang sangat fundamental bagi mereka yang jatuh ke tangan musuh. Kombatan yang jatuh ke tangan musuh berhak diperlakukan sebagai tawanan perang dan harus dilakukan secara manusiawi;

3) Mencegah dilakukannya perang secara kejam tanpa mengenal batas. Di sini yang penting adalah asas perikemanusiaan.

\section{Sumber Hukum Humaniter}

Hukum Humaniter Internasional adalah salah satu bagian dari hukum internasional. Oleh sebab itu aturan-aturan Hukum Humaniter Internasional (HHI) tidak harus bersumber dari perjanjian internasional saja, tapi juga bersumber dari kebiasaan hukum internasional dan 


\section{DE IFGA LATA}

Jurnal Ilmu Hukum

FAKULTAS HUKUM UMSU
Efektivitas Hukum Humaniter...(Mirsa Astuti)

Volume 3 Nomor 1, Januari-Juni 2018, 96-107 DOI: $\underline{\text { https://doi.org/10.30596/dll.v3i1.3143 }}$

prinsip-prinsip hukum yang diakui oleh bangsa-bangsa, keputusan organisasi internasional dan pendapat para ahli (Pasal 38 Statuta Mahkamah Internasional). Contoh dari perjanjian internasional dapat dilihat dalam dua Konvensi utama Hukum Humaniter Internasional, yaitu Hague Convention dan Geneva Convention.

\section{Hague convention (Konvensi Den Haag)}

Sumber yang pertama adalah berasal dari Konvensi Den Haag. Konvensi ini dihasilkan dalam Konvensi Perdamaian Pertama di Den Haag pada tahun 1899, yang kemudian disempurnakan dalam Konferensi ke dua pada tahun 1907. Rangkaian Konvensi tersebut di kenal dengan sebutan Hukum Den Haag.

Dinamakan Den Haag sendiri karena dibuat di wilayah ini (salah satu wilayah di Belanda). Sebenarnya isi dari kedua Konvensi Den Haag, tahun 1899 dan tahun 1907 ini sama yakni mengatur tata cara dan alat yang diperbolehkan dalam perang yang dilakukan oleh Negara-negara yang melakukannya. Hanya saja isi dari Konvensi tahun 1907 merupakan penyempurnaan dari Konvensi tahun 1899. Dalam Konvensi Den Haag Pertama 1899 dihasilkan tiga Konvensi dan tiga deklarasi.

Isi dari tiga Konvensi Den Haag tersebut adalah:

a) Konvensi I tentang Penyelesaian Damai atas Sengketa Internasional

b) Konvensi II tentang Hukum dan Kebiasaan Perang di Darat

c) Konvensi III tentang Adaptasi Azas-azas Konvensi Jenewa tentang Hukum Perang di Laut

Sedangkan tiga Deklarasi yang di hasilkan adalah sebagai berikut:(Athur Nusbaum 1970, h. 158)

a) Melarang penggunaan peluru-peluru dum-dum ( peluru yang bungkusnya tidak sempurna menutup bagian dalam sehingga dapat pecah dan membesar dalam tubuh manusia)

b) Peluncuran proyektil-proyektil dan bahan-bahan peledak dari balon, selama jangka lima tahun yang berakhir di tahun 1905 juga dilarang.

c) Penggunaan proyektil-proyektil yang menyebabkan gas-gas cekik dan beracun dilarang.

Kemudian dalam Konvensi Den Haag 1907, menghasilkan beberapa Konvensi sebagai berikut; (Athur Nusbaum, 1970, h. 160):

a) Konvensi I tentang Penyelesaian Damai Persengketaan Internasional

b) Konvensi II tentang Pembatasan Kekerasan Senjata dalam Menuntut Pembayaran Hutang yang Berasal dari Perjanjian Perdata.

c) Konvensi III tentang Cara Memulai Peperangan

d) Konvensi IV tentang Hukum dan Kebiasaan Perang di Darat dilengkapi dengan Peraturan Den Haag

e) Konvensi V tentang Hak dan Kewajiban Negara dan Orang Netral dalam Perang di Darat

f) Konvensi VI tentang Status Kapal Dagang Musuh Ketika Permulaan Peperangan

g) Konvensi VII tentang Status Kapal Dagang Menjadi Kapal Perang

h) Konvensi VIII tentang Penempatan Ranjau Otomatis di dalam Laut

i) Konvensi IX tentang Pemboman oleh Pasukan Angkatan Laut dimasa Perang

j) Konvensi $\mathrm{X}$ tentang Penyesuaian Prinsip-prinsip Konvensi Jenewa terhadap Perang Laut

k) Konvensi XI tentang Pembatasan Tertentu Terhadap Penggunaan Hak-hak Penangkapan dalam Perang Angkatan Laut

1) Konvensi XII tentang Mahkamah Barang-barang Sitaan 


\section{DE IFGA LATA}

Jurnal Ilmu Hukum

FAKULTAS HUKUM UMSU
Efektivitas Hukum Humaniter...(Mirsa Astuti)

Volume 3 Nomor 1, Januari-Juni 2018, 96-107 DOI: $\underline{\text { https://doi.org/10.30596/dll.v3i1.3143 }}$

m) Konvensi XIII tentang Hak dan Kewajiban Negara Netral dalam Perang di Laut.

\section{Geneva Convention (Konvensi Jenewa)}

Apabila Konvensi Den Haag lebih membahas tentang tata cara serta alat yang dipergunakan dalam berperang, maka dalam Konvensi Jenewa sendiri lebih mengarah kepada tata cara dalam memperlakukan dalam melindungi korban dari perang yang terjadi. Konvensi ini juga sama dengan Den Haag, dimana nama yang diambil berasal dari daerah tempat terjadinya Konvensi ini, yaitu Jenewa yang merupakan salah satu wilayah di Swiss. Konvensi ini terjadi pada tahun 1949. Dalam Konvensi ini terdapat banyak pasal yang sangat mengarah atau membahas tentang cara memperlakukan korban maupun penduduk sipil yang tidak boleh tersentuh ketika perang berlangsung.

Setelah perang dunia kedua, Konvensi ini disempurnakan menjadi empat Konvensi, yang kesemua isinya menyangkut tentang pasal-pasal yang menyangkut tentang perlindungan bagi warga sipil, orang-orang yang tertangkap perang, perlindungan bagi korban perang, serta para pelayan kesehatan dalam perang. Konvensi 1949 menghasilkan empat hukum yang isinya:

a) Geneva Convention for the Amelioration of the Condition of the Wounded and Sick in Armed Forces in the Field (Convention I) - Mengenai Perbaikan Keadaan Anggota Angkatan Bersenjata yang Terluka dan Sakit di Darat.

b) Geneva Convention for the Amelioration of the Condition of Wounded, Sick and Shipwrecked Members of Armed Forces at Sea (Convention II) - Mengenai Perbaikan Keadaan Anggota Angkatan Bersenjata yang Terluka, Sakit, dan Karam di Laut.

c) Geneva Convention relative to the Treatment of Prisoners of War (Convention II) Mengenai Perlakuan Terhadap Tawanan Perang.

d) Geneva Convention relative to Protection of Civilian Persons in Time of War (Convention IV) - Mengenai Perlindungan Orang Sipil di Masa Perang.

\section{Protokol Tambahan 1977}

Selain kedua sumber hukum utama, hukum Humaniter juga mengenal sumber hukum lainnya misalnya Protokol Tambahan 1977 yang disebut dengan hukum campuran karena selain mengatur tentang perlindungan terhadap korban perang dan juga mengatur cara dan alat berperang. Protokol Tambahan ini menambah dan menyempurnakan isi dari Konvensi Jenewa 1949. Perlu ditekankan bahwa prinsip-prinsip yang terdapat dalam Konvensi Jenewa masih tetap berlaku. Protokol Tambahan dibentuk disebabkan metode berperang yang digunakan oleh negara-negara telah berkembang, demikian juga mengenai aturan-aturan atau tata cara berperang. Protokol Tambahan 1977 terdiri dari dua buku, yaitu:

a) Protokol I, yang mengatur perang/ konflik bersenjata yang bersifat internasional yaitu perang/ konflik bersenjata antarnegara.

b) Protokol II, yang mengatur perang/ konflik bersenjata yang sifatnya non-internasional, yaitu perang/konflik bersenjata yang terjadi di wilayah salah satu pihak peserta agung antara pasukanya dengan pasukan pembangkang atau pemberontak. Protokol Tambahan II ini menambah isi ruang lingkup Pasal 3 Konvensi Jenewa.

Beberapa ketentuan pokok Protokol I antara lain menentukan hal-hal sebagai berikut; (Arlina dkk 1999:130)

a) Melarang: serangan yang membabi buta dan reprisal terhadap: 
Jurnal Ilmu Hukum

FAKULTAS HUKUM UMSU
Efektivitas Hukum Humaniter...(Mirsa Astuti) Volume 3 Nomor 1, Januari-Juni 2018, 96-107 DOI: $\underline{\text { https://doi.org/10.30596/dll.v3i1.3143 }}$

1) Penduduk sipil dan orang-orang sipil;

2) Objek-objek yang sangat penting bagi kelangsungan hidup penduduk sipil;

3) Benda-benda budaya dan tempat-tempat relegius;

4) Bangunan dan instalasi berbahaya;

5) Lingkungan alam

b) Memperluas : perlindungan yang sebelumnya telah diatur dalam konvensi Jenewa kepada semua personil medis, unit-unit dan alat-alat transportasi medis, baik yang berasal dari organisasi sipil maupun militer.

c) Menentukan : kewajiban bagi pihak Peserta Agung untuk mencari orang-orang yang hilang (missing persons).

d) Menegaskan : ketentuan-ketentuan mengenai suplai bantuan (relief suplies) yang ditujukan pada penduduk sipil.

e) Memberikan : perlindungan terhadap kegiatan-kegiatan organsasi-organisasi Pertahanan Sipil.

f) Mengkhususkan : adanya tindakan-tindakan yang harus dilakukan oleh negaranegara untuk memfasilitasi implementasi hukum Humaniter.

Sedangkan Protokol Tambahan II karena pada kenyataanya konflik yang terjadi sesudah perang dunia ke II adalah konflik yang bersifat non-internasional. Satu-satunya ketentuan dalam Konvensi Jenewa 1949 yang mengatur tentang sengketa bersenjata non-internasional adalah Pasal 3 common articles. Ketentuan dalam Protokol II antara lain:

a) Mengatur: jaminan-jaminan fundamental bagi semua orang, apakah mereka terlibat ataukah tidak terlibat lagi dalam suatu pertempuran;

b) Menentukan: hak-hak bagi orang-orang yang kebebasanya dibatasi dalam menerima peradilan yang adil;

c) Memberikan: perlindungan penduduk sipil dan objek-objek perlindungan;

d) Melarang: dilakukannya tindakan starvasi secara disengaja.

\section{Pengertian Cagar Budaya}

Cagar budaya adalah warisan budaya bersifat kebendaan berupa Benda Cagar Budaya, Bangunan Cagar Budaya, Struktur Cagar Budaya, Situs Cagar Budaya, dan Kawasan Cagar Budaya di darat dan/atau di air yang perlu dilestarikan keberadaannya karena memiliki nilai penting bagi sejarah, ilmu pengetahuan, pendidikan, agama, dan atau kebudayaan melalui proses penetapan. Pengertian dari benda bersejarah atau peninggalan bersejarah atau benda budaya seperti yang dimaksud dalam Convention for the Protection of Cultural Property in the Event of Armed Conflict Den Haag tahun 1954 terperinci dalam tiga golongan, yaitu:

1) Barang-barang bergerak maupun tidak bergerak yang penting sekali bagi budaya setiap bangsa, seperti monumen arsitektur, tempat-tempat peninggalan bersejarah dan lain-lain;

2) Gedung-gedung yang tujuan utamanya adalah untuk memelihara atau memamerkan barang budaya yang tak ternilai seperti museum, perpustakaan, tempat menyimpan arsip, dan lainlain;

3) Pusat-pusat yang berisikan sejumlah besar barang budaya seperti yang dimaksudkan dalam ayat (a) dan (b) di atas.

Indonesia sendiri telah ada hukum nasional yang mengatur mengenai perlindungan terhadap cagar budaya, termasuk di dalamnya warisan kebendaan dan tempat-tempat yang memiliki nilai penting terhadap sejarah, yakni Undang-Undang Republik Indonesia Nomor 11 


\section{DEIFGA IATA}

Jurnal Ilmu Hukum

FAKULTAS HUKUM UMSU
Efektivitas Hukum Humaniter...(Mirsa Astuti)

Volume 3 Nomor 1, Januari-Juni 2018, 96-107 DOI: $\underline{\text { https://doi.org/10.30596/dll.v3i1.3143 }}$

Tahun 2010 tentang Cagar Budaya. Dalam Pasal 1 UU ini tercantum pengertian cagar budaya dan benda cagar budaya, yakni:

1) Cagar Budaya adalah warisan budaya bersifat kebendaan berupa Benda Cagar Budaya, Bangunan Cagar Budaya, Struktur Cagar Budaya, Situs Cagar Budaya, dan Kawasan Cagar Budaya di darat dan/atau di air yang perlu dilestarikan keberadaannya karena memiliki nilai penting bagi sejarah, ilmu pengetahuan, pendidikan, agama, dan/atau kebudayaan melalui proses penetapan.

2) Benda Cagar Budaya adalah benda alam dan/atau benda buatan manusia, baik bergerak maupun tidak bergerak, berupa kesatuan atau kelompok, atau bagian-bagiannya, atau sisasisanya yang memiliki hubungan erat dengan kebudayaan dan sejarah perkembangan manusia.

3) Bangunan Cagar Budaya adalah susunan binaan yang terbuat dari benda alam atau benda buatan manusia untuk memenuhi kebutuhan ruang berdinding dan/atau tidak berdinding, dan beratap.

Benda atau bangunan yang merupakan cagar budaya sesungguhnya bukan saja harus dilindungi tetapi juga harus dijamin kelestariannya. Untuk dapat disebut sebagai Cagar Budaya, ada beberapa tahap yang harus dilalui, yaitu: tahap pendaftaran, pengkajian, penetapan, pencatatan, pemeringkatan, penghapusan, penyelamatan, pengamanan, zonasi, pemeliharaan, pemugaran, penelitian, revitalisasi, adaptasi dan pemanfaatan.

\section{Perlindungan Cagar Budaya Menurut Hukum Humaniter}

Perlindungan hukum terhadap benda-benda budaya dalam masa konflik bersenjata diatur dalam sebuah instrumen khusus Hukum Humaniter Internasional, yaitu Convention for the Protection of Cultural Property in the Event of Armed Conflict Den Haag Tahun 1954 (Konvensi Den Haag 1954 tentang Perlindungan Benda Budaya Pada Waktu Sengketa Bersenjata). Hukum Humaniter Internasional muncul untuk memberikan perlindungan dan penghormatan terhadap benda budaya. Meskipun demikian, antisipasi untuk menghindari terjadinya impunitas terhadap benda budaya juga sangat memerlukan dukungan dari hukum nasional.

Kendati hukum Humaniter kerap disebut hukum perang, dalam situasi damai hukum Humaniter tetap mengisyaratkan kepada negara untuk melakukan tindakan persiapan dalam rangka perlindungan benda budaya. Penghormatan dan perlindungan terhadap benda budaya merupakan tugas dan kewajiban negara dan masyarakat internasional. Sebab, benda budaya adalah benda yang memuat kepentingan besar warga internasional dan warisan internasional untuk kemanusiaan.

Konvensi Den Haag Tahun 1954 Tentang Perlindungan Benda Budaya Pada Saat Konflik Bersenjata, adalah instrumen hukum universal pertama yang menetapkan pengaturan mengenai perlindungan terhadap benda-benda budaya, dalam hal ini tempat-tempat bersejarah, dalam masa konflik bersenjata. Protokol dari Konvensi ini juga menetapkan pengaturan mengenai perlindungan khusus dalam situasi di mana wilayah suatu negara dikuasai atau diduduki oleh negara lain. Dua dekade kemudian, di dalam Protokol tambahan dari Konvensi Jenewa 1949 ditambahkan pengaturan berkaitan dengan perlindungan terhadap benda-benda budaya, termasuk tempat-tempat bersejarah dalam masa konflik bersenjata internasional dan konflik bersenjata non-internasional; di mana kekebalan yang dimiliki oleh 


\section{DE IFGA LATA}

Jurnal Ilmu Hukum

FAKULTAS HUKUM UMSU
Efektivitas Hukum Humaniter...(Mirsa Astuti)

Volume 3 Nomor 1, Januari-Juni 2018, 96-107 DOI: $\underline{\text { https://doi.org/10.30596/dll.v3i1.3143 }}$

benda-benda warga sipil atau obyek-obyek sipil juga diberikan kepada tempat-tempat bersejarah. Di dalam Protokol-protokol ini dengan jelas mengatur bahwa pihak-pihak yang berperang dilarang untuk menjadikan tempat-tempat bersejarah sebagai sasaran militer untuk diserang dan dirusak terlebih dihancurkan, dan untuk melakukan tindakan penyanderaan terhadap tempat-tempat bersejarah.

Di dalam Konvensi Den Haag tahun 1954, prinsip umum atas perlindungan terhadap benda-benda budaya yang bersejarah didasarkan pada obligasi untuk menjaga dan menghormati tempat bersejarah tersebut, seperti dijelaskan dalam Pasal 2 Konvensi. Penjagaan atas tempat bersejarah terdiri dari setiap langkah persiapan yang harus diambil di dalam masa damai demi tersedianya kondisi terbaik bagi perlindungan tempat bersejarah tersebut, seperti yang tercantum dalam Pasal 3. Sementara itu, penghormatan terhadap tempat bersejarah berarti menghindari tindakan permusuhan yang ditujukan langsung terhadap tempat bersejarah tersebut, dan melarang, mencegah dan jika perlu menghentikan segala bentuk pencurian, penjarahan atau penyalahgunaan, dan setiap tindakan-tindakan vandalisme yang ditujukan langsung terhadap tempat bersejarah tersebut. Hal tersebut juga berarti bahwa penggunaan tempat bersejarah untuk tujuan militer dan untuk mendukung tindakan militer adalah dilarang, seperti yang ditegaskan pada Pasal 4. Tindakan pembalasan yang ditujukan langsung terhadap tempat-tempat bersejarah juga dilarang, dan tidak ada alasan pembenar atau pengecualian untuk tindakan pembalasan, ditegaskan dalam Pasal 4 paragraf 4, dan terkandung dalam Pasal 53(c) dari Protokol Tambahan I 1977.

Langkah-langkah yang harus diambil untuk menjamin bahwa tempat-tempat bersejarah itu terlindungi dan dihormati harus dilakukan dengan identifikasi dan inventarisasi, lambang, kartu identitas, pendaftaran di International Register of Property under Special Protection, penyebaran dan sanksi pidana, penjelasan sebagai berikut:

1) Identifikasi dan Inventarisasi

Tempat-tempat bersejarah tersebut harus diidentifikasi dan didaftarkan. Identifikasi yakni suatu tindakan untuk menentukan dan mempertimbangkan apakah tempat bersejarah tersebut benar-benar memiliki nilai sejarah dan kebudayaan yang memerlukan perlindungan. Perlindungan ini didapatkan bersamaan dengan tanggung jawab dari elemen pemerintahan nasional. Inventarisasi yakni suatu tindakan mendaftarkan semua tempat-tempat bersejarah yang dilindungi dan daftar-daftar ini diserahkan pada badan-badan yang mengatur mengenai perlindungan terhadap properti bersejarah. Inventarisasi ini memuat informasi seperti berikut:

a) Detail-detail umum mengenai tempat bersejarah tersebut;

b) Informasi sah mengenai registrasinya di registrasi negara;

c) Detail dari pemiliknya;

d) Tujuan penggunaan dari tempat bersejarah tersebut (publik, pendidikan, keagamaan, dan lain-lain);

e) Asal usul nilai dari tempat bersejarah tersebut (arkaeologikal, historikal, artistik, dan lainlain);

f) Detail mengenai asal-muasalnya (konstruksi, tahun, periode, style, dan lain-lain);

g) Pengukuran-pengukuran, bahan-bahan dan teknik-teknik yang digunakan;

h) Deskripsi dari tempat bersejarah tersebut; 


\section{DE IFGA LATA}

Jurnal Ilmu Hukum

FAKULTAS HUKUM UMSU
Efektivitas Hukum Humaniter...(Mirsa Astuti)

Volume 3 Nomor 1, Januari-Juni 2018, 96-107 DOI: $\underline{\text { https://doi.org/10.30596/dll.v3i1.3143 }}$

i) Detail-detail dari data grafis yang disimpan di dalam arsip tempat bersejarah tersebut: dokumen-dokumen, foto-foto, model, informasi audio-visual, dan lain-lain.

Sangat disarankan untuk memiliki dokumentasi simpanan untuk menjamin bahwa apabila tempat bersejarah itu rusak atau hancur, tempat bersejarah tersebut dapat dibangun kembali. Tergantung dari tipe dari tempat bersejarah tersebut, beragam cara dapat digunakan untuk mengumpulkan referensi dokumentasinya.

\section{2) Lambang Pembeda}

Tempat bersejarah bisa (di dalam kasus perlindungan umum, Pasal 6) atau harus (dalam perlindungan khusus, Pasal 10) ditandai dengan lambang. Lambang pembeda adalah sebagai berikut, menurut Pasal 16.

a) Lambang pengenal dalam Konvensi ini berupa tameng yang mengarah kebawah dengan saltir biru dan putih (sebuah tameng yang terdiri dari suatu segi empat sama sisi biru yang salah satu sudutnya merupakan ujung dari tameng, dan sebuah segitiga sama sisi biru yang berada pada bagian atas; ruang disisi kiri dan kanannya terdiri dari masing-masing sebuah segitiga warna putih).

b) Lambang harus digunakan sebuah, atau digunakan tiga buah dalam formasi segitiga (satu tameng dibawah), menurut syarat-syarat yang ditentukan dalam Pasal 17. Tempat untuk meletakkan lambang tersebut diatur oleh masing-masing negara. Dalam kasus sengketa bersenjata tahun 1991 di Kroasia, lambang tersebut dilukis di sebuah papan dan diletakkan di tempat setinggi dua meter, di ratusan monumen-monumen dan institusi-institusi yang dilindungi. Menurut Pasal 17, lambang pembeda tidak boleh digunakan di tempat bersejarah kecuali pada saat yang sama ada suatu otorisasi yang dapat diperlihatkan sepatutnya dan ditandatangani oleh penguasa yang berwenang dari negara yang bersangkutan.

3) Kartu Identitas.

Orang-orang yang bertanggung jawab untuk melindungi tempat bersejarah memegang kartu identitas khusus dengan lambang pembeda. Kartu ini mencantumkan marga dan nama awal, tanggal lahir, titel atau pangkat, dan tugas dari orang tersebut. Di kartu tersebut juga tertera foto dari pemilik, juga tanda tangan mereka atau cap jari atau keduanya. Selain itu, di kartu tersebut harus tertera cap dari otorisasi yang berwenang. Spesimen dari kartu yang digunakan harus diserahkan kepada negara-negara peserta Konvensi yang lain sebagai informasi bagi mereka.

\section{4) International Register of Property under Special Protection.}

Tempat-tempat penampungan, pusat-pusat yang memuat monumen-monumen dan benda-benda tidak bergerak lainnya yang berada di bawah perlindungan khusus (special protection) harus didaftarkan di International Register of Cultural Property under Special Protection, yang dikelola oleh Direktur-Jenderal UNESCO. Untuk mendapatkan hak perlindungan khusus, pemerintah nasional harus mengirimkan deskripsi lokasi dan segala persyaratan yang menjelaskan bahwa tempat bersejarah tersebut memenuhi kriteria untuk dilindungi secara khusus.

5) Penyebaran (Dissemination). 


\section{DE IFGA LATA}

Jurnal Ilmu Hukum

FAKULTAS HUKUM UMSU
Efektivitas Hukum Humaniter...(Mirsa Astuti)

Volume 3 Nomor 1, Januari-Juni 2018, 96-107 DOI: $\underline{\text { https://doi.org/10.30596/dll.v3i1.3143 }}$

Agar supaya pengetahuan mengenai instrumen-instrumen hukum ini dapat tersebar, adalah hal yang sangat penting bahwa teks dari Konvensi Den Haag tahun 1954 ini beserta Aturan Pelaksanaannya untuk diterjemahkan ke dalam bahasa-bahasa nasional. Bahasabahasa resmi untuk Konvensi Den Haag tahun 1954 dan Protokol I-nya adalah Bahasa Inggris, Bahasa Perancis, Bahasa Spanyol dan Bahasa Rusia. Terjemahan resmi ke dalam bahasa lain harus dikirimkan ke Direktur Jenderal UNESCO sebagai komunikasi untuk negara-negara peserta Konvensi yang lain, seperti yang tercatat dalam Pasal 26. Protokol II dibuat dalam bahasa Inggris, bahasa Perancis, bahasa Spanyol, bahasa Mandarin dan bahasa Arab. Obligasi-obligasi untuk perlindungan tempat bersejarah yang terdapat dalam Konvensi ini harus disebarluaskan sebisa mungkin. Untuk melakukan hal tersebut:

a) Aturan-aturan internasional dan obligasi-obligasi nasional yang terdapat dari instrumeninstrumen ini harus dimasukkan ke dalam aturan-aturan militer, dan spirit penghargaan terhadap budaya dan tempat bersejarah harus ditanamkan di antara tentara-tentara dalam masa damai (Pasal 7 dan 25)

b) Pembelajaran atas aturan-aturan dan obligasi-obligasi ini harus diperluas agar supaya prinsip-prinsip yang terkandung di dalam instrumen-instrumen ini diketahui oleh seluruh populasi, khususnya orang-orang yang terlibat di dalam perlindungan tempat bersejarah (Pasal 25).

Agar supaya peraturan-peraturan ini ditaati, adalah hal yang pasti untuk setiap pelanggaran mendapatkan sanksi. Penyusun sanksi pidana nasional harus menyediakan sanksi atas orang-orang yang telah melakukan pelanggaran atas Konvensi Den Haag tahun 1954 atau telah memerintahkan dibuatnya pelanggaran, tidak peduli kewarganegaraan mereka (Pasal 28). Selama masa konflik, setiap pihak yang bersengketa harus:

a) Menghindari menggunakan tempat bersejarah dan sekelilingnya yang dilindungi untuk tujuan yang memungkinkan tempat bersejarah itu untuk menghadapi kerusakan dan kehancuran, terkecuali dalam keadaan militer yang mendesak (Pasal 4, paragraf 1 dan 2);

b) Menghindari segala bentuk tindakan permusuhan yang diarahkan langsung kepada tempattemat bersejarah, terkecuali dalam keadaan militer yang mendesak (Pasal 4, paragraf 1 dan 2);

c) Melarang, mencegah dan menghentikan segala bentuk pencurian, penjarahan atau penyalahgunaan dan segala tindakan vandalisme (Pasal 4, paragraf 3);

d) Menghindari tindakan mengklaim tempat bersejarah yang terletak di teritori negara lain (Pasal 4, paragraf 3);

e) Menghindari segala bentuk tindakan pembalasan yang diarahkan langsung terhadap tempat bersejarah (Pasal 4, paragraf 4);

f) Menghindari segala bentuk tindakan permusuhan yang diarahkan terhadap tempat bersejarah dan penggunaan tempat bersejarah yang dilindungi secara khusus untuk tujuantujuan militer (Pasal 9). Selama masa okupasi atau pendudukan negara lain atas wilayah suatu negara, negara yang mengokupasi harus:

g) Mendukung otorisasi nasional yang kompeten dari negara yang diduduki itu dalam hal penjagaan dan perlindungan tempat bersejarah;

h) Mengambil semua langkah yang diperlukan untuk penjagaan dan perlindungan dengan kerjasama yang dekat dengan otorisasi nasional yang kompeten, apabila otorisasi nasional ini tidak dapat berbuat demikian; 


\section{DE IFGA LATA}

Jurnal Ilmu Hukum

FAKULTAS HUKUM UMSU
Efektivitas Hukum Humaniter...(Mirsa Astuti)

Volume 3 Nomor 1, Januari-Juni 2018, 96-107 DOI: $\underline{\text { https://doi.org/10.30596/dll.v3i1.3143 }}$

i) Menunjuk perwakilan khusus untuk tempat bersejarah yang terletak di daerah yang diduduki.

Harus ditekankan bahwa tanggung jawab yang terkandung di dalam segala peraturan instrumen-instrumen hukum Humaniter internasional ditujukan kepada kedua belah pihak yang terlibat dalam konflik, baik pihak yang mengontrol tempat bersejarah dan pihak yang menyerang atau pihak lawan. Teori military necessity adalah satu-satunya alasan di mana kewajiban negara-negara untuk menghormati tempat bersejarah dapat diabaikan. Teori yang tercantum di dalam Konvensi Den Haag 1954 ini adalah hal yang sangat disayangkan, mengingat teori ini adalah pembenaran terhadap pelanggaran atas perlindungan tempat-tempat bersejarah.

Meskipun demikian, penggunaan teori kepentingan militer tidak tanpa batasan. Menurut Nobuo Hayashi, sekurang-kurangnya ada empat persyaratan penggunaan teori kepentingan militer, yakni:

a) Langkah yang diambil dengan menggunakan teori kepentingan militer harus memiliki tujuan militer yang spesifik;

b) Langkah yang diambil harus benar-benar diperlukan untuk pencapaian tujuan militer;

c) Tujuan militer yang dimaksud harus sesuai dengan hukum Humaniter internasional;

d) Langkah yang diambil tersebut harus sesuai dengan hukum Humaniter internasional.

Menilik pada tindakan pengrusakan tempat bersejarah yang dilakukan oleh oknumoknum yang tidak bertanggungjawab dengan bersembunyi di balik teori kepentingan militer tanpa memperhatikan batasan-batasan dan persyaratan yang diperlukan, tentu saja hal tersebut adalah suatu pelanggaran besar. Menurut ICTY (International Criminal Tribunal for the former Yugoslavia) Statute, pengrusakan bahkan penghancuran terhadap tempat yang dilindungi adalah pelanggaran terhadap Konvensi Jenewa 1949, pelanggaran terhadap hukum perang, dan merupakan tindakan kejahatan terhadap kemanusiaan. Sanksi terhadap pelanggaran hukum Humaniter internasional diatur di dalam Konvensi Jenewa 1949 dalam ketentuan tentang 'penal sanctions'. Menurut Starke, sanksi-sanksi hukum Humaniter internasional terhadap kejahatan perang antara lain pembalasan (reprisal), penghukuman baik selama maupun sesudah permusuhan berakhir terhadap penjahat-penjahat perang melalui suatu pengadilan yang layak.

\section{KESIMPULAN DAN SARAN Kesiimpulan}

Benda budaya merupakan identitas budaya masyarakat, sehingga serangan terhadapnya sering meningkatkan ekskalasi konflik. Serangan pemboman dari udara dan dari jarak jauh menambah kerusakan benda budaya akibat dari konflik bersenjata. Antisipasi impunitas atas pelanggaran perlindungan benda budaya dari dampak konflik bersenjata perlu dikuatkan dalam hukum internasional dengan dukungan hukum nasional. Perlindungan hukum terhadap benda-benda budaya dalam masa konflik bersenjata diatur dalam sebuah instrumen khusus hukum Humaniter internasional, yaitu Convention for the Protection of Cultural Property in the Event of Armed Conflict Den Haag Tahun 1954 (Konvensi Den Haag 1954 tentang Perlindungan Benda Budaya Pada Waktu Sengketa Bersenjata), dan Protokol Tambahan II Tahun 1999.

\section{Saran}


Jurnal Ilmu Hukum

FAKULTAS HUKUM UMSU
Efektivitas Hukum Humaniter...(Mirsa Astuti) Volume 3 Nomor 1, Januari-Juni 2018, 96-107 DOI: $\underline{\text { https://doi.org/10.30596/dll.v3i1.3143 }}$

Kedepan antisipasi impunitas atas pelanggaran perlindungan benda budaya dari dampak konflik bersenjata perlu dikuatkan dalam hukum internasional dengan dukungan hukum nasional serta perlindungan hukum terhadap benda-benda budaya dalam masa konflik bersenjata harus diatur dalam sebuah instrumen khusus hukum humaniter internasional, agar benda budaya dari dampak konflik bersenjata dapat lebih terjamin perlindungannya.

\section{DAFTAR PUSTAKA}

Departemen Kehakiman RI. 1999. Konvensi Jenewa Tahun 1949. Geneva Convention of 1949. Direktoral Jenderal Hukum dan Perundang-Undangan Departemen Kehakiman Jakarta.

Effendi, Masjur., Ridwan, Moh., Subandi, Muslich. (1995). Pengantar dan Dasar-dasar Hukum Internasional. IKIP Malang. Malang.

Haryomataram. (2007). Pengantar Hukum Humaniter. PT Raja Grafindo Persada. Jakarta.

Istanto, Sugeng. (2010). Hukum Internasional. Universitas Atmajaya Yogjakarta

Kusumaatmadja, Mochtar. (1980). Hukum Internanional Humaniter dalam Pelaksanaan dan penerapanya di Indonesia. Bandung: Bina Cipta.

Marzuki, Peter Mahmud. (2011). Penelitian Hukum. Jakarta: Kencana Prenada Media Group.

Nusbaum, Athur. (1970). Sejarah Hukum Internasional. Jilid 1. Bandung: Bina Cipta.

Permanasari, Arlina dkk. (1999). Pengantar Hukum Humaniter. Jakarta: ICRC.

Seokanto, Sorejono \& Muji, Sri. (1996). Pengantar Penelitian Hukum. Jakarta: UI Press.

Seokanto, Sorejono \& Muji, Sri. (2003). Penelitian Hukum Normatif Suatu Tinjauan Singkat. Jakarta: Rajawali Pers.

Starke, J.G. (1989). Pengantar Hukum Internasional. Jakarta: Sinar Grafika. 